\title{
INDEKSY SPOŁECZNEJ ODPOWIEDZIALNOŚCI JAKO METODA POMIARU DZIAŁAŃ CSR W PRZEDSIĘBIORSTWACH
}

\section{WSTĘP}

Gospodarka pojmowana jako całość mechanizmów i warunków działania podmiotów gospodarczych związana z wytwarzaniem i podziałem dóbr i usług nieustannie oddziałuje na społeczności i środowisko naturalne. Niezwykle pozytywnym zjawiskiem jest wzrost znaczenia koncepcji społecznej odpowiedzialności biznesu w życiu gospodarczym na całym świecie. Wyrazem tego procesu jest coraz większa liczba przedsiębiorców stosujących dobre praktyki z zakresu CSR, co pokazują coroczne raporty „Odpowiedzialny biznes w Polsce 2015. Dobre praktyki” publikowane przez Forum Odpowiedzialnego Bizne$\mathrm{su}^{1}$. Lektura raportów pozwala stwierdzić, że przedsiębiorstwa prześcigają się w aranżowaniu i wdrażaniu coraz to ciekawszych rozwiązań na rzecz racjonalizowania warunków społecznych i środowiskowych. Wart odnotowania jest fakt, że dla wielu przedsiębiorstw celem działania jest nie tylko maksymalizacja zysku, lecz także zrównoważony rozwój, którego istotą jest sprzężenie rozwoju gospodarczego i społecznego ze wzrostem jakości środowiska naturalnego. Przedsiębiorstwa społecznie odpowiedzialne to takie, które w swojej działalności uwzględniają nie tylko cele ekonomiczne, ale także dbają o kwestie społeczne i środowiskowe. Istnieje szereg norm i standardów regulujących społeczną odpowiedzialność biznesu, oprócz nich jednak niezwykle istotne wydaje się określenie narzędzi pozwalających na ocenę społecznej odpowiedzialności podmiotów gospodarczych. Jednym ze sposób takiej oceny są giełdowe indeksy spółek społecznie odpowiedzialnych, które to sa przedmiotem rozważań autora niniejszego artykułu. Celem publikacji jest analiza indeksów społecznej odpowiedzialności pod kątem ich rzeczywistego, praktycznego wykorzystania i wpływu na decyzje podejmowane przez inwestorów. Pozwoli to stwierdzić, czy indeksy społecznej odpowiedzialności są efektywnym sposobem pomiaru CSR spełniającym oczekiwania rynku. W opinii autora indeksy społecznej odpowiedzialności są rzadko wykorzystywane przez inwestorów, jako wskaźnik pozwalający na bezpieczne ulokowanie kapitału. Coraz większa znajomość indeksów przez uczestników rynku kapitałowego wciąż nie przekłada się na ich rzeczywistą użyteczność.

${ }^{1}$ Raport „Odpowiedzialny biznes w Polsce 2015. Dobre praktyki”, http://odpowiedzialnybiznes.pl/publikacje/raport-2015/ [dostęp: 14.03.2017]. 
W części wprowadzającej artykułu autor przedstawia istotę społecznej odpowiedzialności biznesu; następnie analizuje uwarunkowania rozwoju tej idei. W dalszej części prezentuje najważniejsze indeksy społecznej odpowiedzialności na świecie z uwzględnieniem amerykańskiego Dow Jones Sustainability Index oraz brytyjskiego FTSE4GOOD Index, a także szczegółowo wskazuje założenia indeksu RESPECT publikowanego przez Giełdę Papierów Wartościowych w Warszawie (GPW) oraz na podstawie przeprowadzonych badań metoda analizy treści i desk research formułuje wnioski dotyczące praktyczności indeksów społecznej odpowiedzialności.

\section{ISTOTA IDEI SPOŁECZNEJ ODPOWIEDZIALNOŚCI BIZNESU}

Społeczna odpowiedzialność biznesu jest pojęciem, które nie doczekało się dotychczas w literaturze przedmiotu jednoznacznej definicji mogącej w pełni oddać sens tej idei. W zależności od autora i jego perspektywy społeczna odpowiedzialność traktowana jest w różny sposób. Do różnego postrzegania społecznej odpowiedzialności odniosła się Halina Zboroń, wyróżniając trzy podstawowe jej ujęcia ${ }^{2}$.

CSR jest elementem dodatkowym dla kluczowego celu przedsiębiorstwa, którym jest maksymalizacja zysku, zgodnie z twierdzeniem Miltona Friedmana $^{3}$. W tym podejściu odchodzi się od konieczności wdrażania praktyk społecznie odpowiedzialnych, które mogłyby przyczynić się do strat finansowych organizacji.

Społeczna odpowiedzialność traktowana jest również jako element Public Relations, który ma za zadanie budować pozytywne relacje między organizacją a określoną grupą odbiorców przekazu. Podejście to traktuje CSR jako narzędzie komunikacji marketingowej przynoszące korzyści wizerunkowe, a w ich rezultacie także wymierne efekty finansowe $e^{4}$.

Wyróżnia się także podejście filantropijne, według którego działania z zakresu społecznej odpowiedzialności przeprowadzane sa bezinteresownie, a sam CSR jest wyrazem potrzeby serca i społecznego obowiązku. Takie ujęcie prezentuje Lidia Zbiegień-Maciąg, która definiuje CSR jako moralną odpowiedzialność firmy i zobowiązania do rozliczania się przed społeczeństwem ze swojej działalności, w szczególności przed właścicielami, klientami wewnętrznymi - pracownikami oraz akcjonariuszami i klientami zewnętrznymi, akcjonariuszami i przedstawicielami władz lokalnych, grupa-

${ }^{2}$ H. Zboroń, Dyskurs o społecznej odpowiedzialności ekonomistów (z kryzysem $w$ tle), w: Z. Pisz, M. Rojek-Nowosielska (red.), Społeczna odpowiedzialność organizacji. Polityczna poprawność czy obywatelska postawa?, Wyd. UE we Wrocławiu, Wrocław 2011, s. 32-34.

${ }^{3}$ M. Friedman, Społeczna odpowiedzialność biznesu to zwiększanie zysków, tłum. H. Simbierowicz, Z. Wiankowska-Ładyka, w: G. D. Chryssides, J. H. Kaler (red.), Wprowadzenie do etyki biznesu, PWN, Warszawa 1999, s. 261.

${ }^{4}$ M. Stefańska, CSR a wartosć przedsiębiorstwa, w: Z. Pisz, M. Rojek-Nowosielska (red.), op. cit., s. 303. 
mi nacisku, ruchami ekologicznymi, konsumenckimi, dostawcami oraz kooperantami i administracja państwową ${ }^{5}$.

Aby w pewien sposób pogodzić różne ujęcia, CSR można zdefiniować jako ideę zakładająca świadome podejmowanie działań w obszarze społecznym, środowiskowym oraz ładu korporacyjnego wykraczajacych poza statutowa działalność przedsiębiorstwa.

\section{UWARUNKOWANIA ROZWOJU CSR}

Zauważyć można, że w ostatnich latach zmienia się pojmowanie przez przedsiębiorców i inwestorów celów prowadzenia działalności gospodarczej. Odchodzi się od koncepcji zakładających, że najważniejszym celem funkcjonowania podmiotu gospodarczego jest maksymalizacja zysku. Firmy muszą się przystosowywać do nieustannie zmieniajacych się warunków, powinny uwzględniać nie tylko swoje cele ekonomiczne, lecz także aspekty środowiskowe, społeczne oraz ład korporacyjny. Wynika to m.in. z faktu, że coraz większa liczba podmiotów finansuje swoją działalność przez wykorzystanie rynków kapitałowych, co wymusza na nich uwzględnianie różnych grup interesu w zarządzaniu przedsiębiorstwem. Dla interesariuszy niezwykle istotny jest wzrost wartości przedsiębiorstwa, który w dużej mierze opiera się na jego zrównoważonym rozwoju i uwzględnianiu działań z zakresu społecznej odpowiedzialności. Jednym z czynników, które znacznie wpłynęły na zmianę w ocenie atrakcyjności inwestycyjnej danych podmiotów, jest ostatni kryzys finansowy zapoczątkowany w $2007 \mathrm{r}$. oraz jego globalne konsekwencje, które pokazały, że odpowiedzialne zachowania biznesowe mają ogromny wpływ na stabilność rynku finansowego ${ }^{6}$. Szczególnego znaczenia w kwestii podejmowania decyzji inwestycyjnych nabiera idea inwestowania odpowiedzialnego społecznie (socially-responsible investing - SRI) nazywana również zrównoważonym inwestowaniem lub etycznym inwestowaniem. Istnieje wiele różnych definicji inwestowania odpowiedzialnego społecznie, wszystkie jednak posiadaja pewne wspólne elementy, które to zostały uwzględnione w definicji etycznego inwestowania przedstawionego przez Europejski Komitet Ekonomiczno-Społeczny:

Etyczne inwestowanie ma na celu finansowanie inicjatyw związanych ze środowiskiem naturalnym, zrównoważonym rozwojem, usługami społecznymi, kulturą i współpracą międzynarodowa. W tym wypadku wyboru papierów wartościowych dokonuje się nie tylko z zastosowaniem tradycyjnych kryteriów finansowych, ale również na podstawie kryteriów z zakresu odpowiedzialności społecznej, takich jak jakość stosunku pracy, poszanowanie środowiska naturalnego, przejrzystość 7 .

\footnotetext{
${ }^{5}$ L. Zbiegień-Maciag, Etyka w zarzadzaniu, PWN, Warszawa 1991, s. 48-49.

${ }^{6}$ N. C. Smith, G. Lenssen, Odpowiedzialność biznesu. Teoria i praktyka, Studio EMKA, Warszawa 2009 .

${ }^{7}$ Opinia Europejskiego Komitetu Ekonomiczno-Społecznego w sprawie: Wymiar etyczny $i$ spoteczny europejskich instytucji finansowych, http://eur-lex.europa.eu/legal-content/PL/ ALL/?uri=CELEX:52008IE1680 [dostęp: 10.03.2017].
} 
W związku z rosnącym znaczeniem idei SRI wśród inwestorów podmioty kompleksowo modyfikuja swoje systemy zarządzania, uwzględniając zasady społecznej odpowiedzialności biznesu, przedstawiaja raporty niefinansowe oraz wdrażają kodeksy etyczne w organizacji. Rośnie świadomość firm w zakresie konieczności dostosowania się do zmieniających się warunków rynkowych, które wymuszają skorelowanie działalności z kwestiami społecznymi i środowiskowymi. Nieuwzględnienie aspektów społecznej odpowiedzialności wiąże się z ponoszeniem kilku rodzajów ryzyka. Ryzyko reputacyjne wynikające ze złego zrozumienia oczekiwań otoczenia, czego efektem może być kryzys reputacji firmy skutkujący np. spadkiem liczby klientów. Uwzględnienie czynników ESG, czyli czynników społecznych, środowiskowych i ładu korporacyjnego, przyczynia się do budowania dobrej reputacji firmy odnoszącej się $\mathrm{z}$ szacunkiem do otoczenia. Innym rodzajem ryzyka jest ryzyko finansowo-operacyjne. Nieuwzględnienie w działalności aspektów ekologicznych czy też etycznych $\mathrm{w}$ relacjach $\mathrm{z}$ interesariuszami może wiązać się ze znacznymi stratami finansowymi. Przykładem może być tutaj kara blisko 30 milionów złotych nałożona przez Urząd Ochrony Konkurencji i Konsumentów na Orange Polska za bezprawnie przedłużanie umów o świadczenie usług stacjonarnych o wiele miesięcy bez wyraźnej zgody konsumentów. Jeszcze innym rodzajem jest ryzyko niskiego poziomu zaangażowania pracowników. Brak wyraźnych działań na rzecz zadowolenia pracowników może negatywnie wpływać na ich zaangażowanie oraz motywację do pracy. W konsekwencji prowadzić to może do spadku efektywności pracy oraz częstej fluktuacji kadr. Ponadto wyróżnić można także ryzyko braku akceptacji działalności wynikające z nieuwzględnienia opinii i oczekiwań interesariuszy ${ }^{8}$. Wynikiem takiego podejścia może być brak społecznej akceptacji dla firmy, skutkujący m.in. brakiem nowych zamówień czy trudnością z pozyskiwaniem inwestorów. Przedstawione rodzaje ryzyka jednoznacznie wskazują konieczność uwzględnienia w działalności oczekiwań poszczególnych interesariuszy podmiotu gospodarczego. Zestawienie tych oczekiwań przedstawia tabela 1.

\section{Tabela 1}

Oczekiwania interesariuszy przedsiębiorstwa

\begin{tabular}{|l|l|l|}
\hline \multicolumn{1}{|c|}{ Interesariusz } & \multicolumn{1}{|c|}{ Oczekiwania pierwotne } & \multicolumn{1}{c|}{ Oczekiwania wtórne } \\
\hline Właściciele & Zwrot kapitału & Wartość dodana \\
Pracownicy & Otrzymanie wynagrodzenia & Zadowolenie z pracy \\
Klienci & Dostarczenie towaru & Jakość \\
Dostawcy & Otrzymanie zapłaty & Długa współpraca \\
Społeczeństwo & Bezpieczeństwo, jakość & Działania prospołeczne \\
Rząd & Współdziałanie & Doskonalenie współdziałania \\
\hline
\end{tabular}

Źródło: B. Wawrzyniak: Odnawianie przedsiębiorstwa. Na spotkanie XXI wieku, Poltext, Warszawa 1999, s. 215.

8 CSR: nowy rozdziat praktyki biznesowej, w: L. Anam, E. Szul-Skjoeldkrona, E. Zamościńska, Jak zyskać na odpowiedzialności?, CSRinfo, Warszawa 2012, s. 7. 
Powyższa tabela obrazuje mnogość oczekiwań, które firma, chcąc działać społecznie odpowiedzialnie, powinna uwzględniać w swojej bieżącej działalności. Podmioty gospodarcze zdają sobie sprawę z konieczności uwzględnienia oczekiwań otoczenia, w którym działaja, wprowadzają działania na rzecz sprawozdawczości z zakresu CSR. Organizacje coraz częściej decydują się na prowadzenie spójnej, przejrzystej i efektywnej polityki informacyjnej w celu budowania zaufania wobec swojej działalności. Praktyczne działania przedsiębiorstw w tym zakresie pociagnęły za sobą konieczność opracowania różnego typu mierników, standardów oraz narzędzi pomiaru działań z zakresu społecznej odpowiedzialności. Niezwykle trudno obiektywnie ocenić społeczna aktywność przedsiębiorstw, gdyż brak jednej metody pomiaru CSR, która pozwoliłaby na zmierzenie ekonomicznej efektywności działań z zakresu społecznej odpowiedzialności ${ }^{9}$. Kategoryzacji różnych metod pomiaru CSR dokonała Martyna Wronka ${ }^{10}$, dzieląc je na:

- benchmarking osiagnięć i narzędzia rankingowe,

- certyfikacje i akredytacje,

- wytyczne dotyczące sprawozdawczości,

- sieci oparte na zasadzie dobrowolnego udziału,

- analizy treści publikacji korporacyjnych,

- skale ocen,

- tworzenie cząstkowych wskaźników w ramach karty wyników (balance scorecard-BSC).

Wśród wielu narzędzi i metod oceny CSR, które można dopasować do wyżej wymienionych kategorii, warto dokonać analizy istotnych z punktu widzenia niniejszego opracowania indeksów społecznej odpowiedzialności, opierających się na ogólnodostępnych informacjach.

\section{GIEŁDOWE INDEKSY SPOŁECZNEJ ODPOWIEDZIALNOŚCI NA ŚWIECIE}

Rozwój koncepcji CSR sprawił, że coraz większym powodzeniem wśród inwestorów cieszą się narzędzia pozwalające w pewnym stopniu ocenić działalność spółek pod kątem ich społecznej odpowiedzialności. Szczególne znaczenie sprawozdawczości w tym zakresie jest zauważalne po ostatnim kryzysie finansowym, który nadszarpnął zaufanie na rynku globalnym. To właśnie w odpowiedzialności społecznej inwestorzy próbują szukać stabilności i bezpieczeństwa swoich portfeli inwestycyjnych, upatrując w niej wyznacznika poprawnego funkcjonowania działalności i podstawy do budowania wiarygodności spółki. Warto jednak zwrócić uwagę na stosunkowo duże problemy w ocenie

${ }^{9}$ E. Stawecka, Ekonomiczna efektywność społecznej odpowiedzialności w biznesie, w: J. Wołoszyn (red.), Społeczna odpowiedzialność biznesu w obszarze przedsiębiorczości, Wyd. SGGW, Warszawa 2012, s. 61.

${ }^{10}$ M. Wronka, Metody pomiaru CSR, w: M. Bonikowska, M. Grewiński (red.), Ustugi społeczne odpowiedzialnego biznesu, TWP, Warszawa 2011, s. 261. 
działalności społecznej przedsiębiorstw, które przejawiają się przede wszystkim w ograniczonym dostępie do informacji. W odpowiedzi na oczekiwania inwestorów powstały indeksy społecznej odpowiedzialności - składają się na nie akcje spółek, które w największym stopniu uwzględniają w swojej działalności kwestie ekologiczne, społeczne i ekonomiczne, takie jak: ład korporacyjny czy przeciwdziałanie łapówkarstwu. Indeksy te wyznaczaja standardy w aspekcie społecznej odpowiedzialności biznesu, a także są właściwym fundamentem pod benchmarking, czyli porównywanie wyników spółek ${ }^{11}$. Warto także zauważyć, że tego typu indeksy wpływają na ciagły udoskonalanie praktyk w zakresie CSR przez przedsiębiorstwa, w celu utrzymania się w indeksie albo wejścia w jego skład. Obecnie funkcjonuje kilkadziesiąt indeksów giełdowych uwzględniających spółki wyróżniające się społeczną odpowiedzialnością swojej działalności. Do tych najbardziej popularnych zalicza się przede wszystkim indeksy z grup Dow Jones Sustainability Index i FTSE4GOOD Index. Warto zauważyć, że mowa nie o pojedynczych indeksach, ale o grupach indeksów. Wynika to ze wzrostu zainteresowania kwestiami społecznej odpowiedzialności wśród uczestników rynku, który doprowadził do coraz bardziej szczegółowej klasyfikacji spółek m.in. ze względu na ich wielkość, branże, w których działaja, czy też ze względu na waskie kryterium CSR ${ }^{12}$. Wybrane światowe indeksy społecznej odpowiedzialności zaprezentowano w tabeli 2.

Początki indeksów z grupy Dow Jones Sustainability sięgają 1999 r., kiedy Dow Jones, STOXX Limited i SAM Group zdecydowały się na opracowanie wskaźnika pozwalajacego na wspomaganie decyzji inwestycyjnych przez identyfikowanie tych spółek, które cechują się najwyższym stopniem realizacji koncepcji społecznej odpowiedzialności ${ }^{13}$. Klasyfikacja spółek przeprowadzana jest na podstawie kompleksowej oceny długoterminowych kryteriów ekonomicznych, społecznych i środowiskowych. Kryterium ekonomiczne to przede wszystkim analiza spółki pod kątem ładu korporacyjnego, zarządzania ryzykiem, kodeksu postępowania, przeciwdziałaniu korupcji i łapówkarstwu. Analiza czynników społecznych opiera się na zbadaniu działalności firmy w takich obszarach, jak: praktyka zatrudnienia, programy rozwoju pracowników, systemy rekrutacji talentów, działalność filantropijna czy sprawozdawczość w zakresie społecznej odpowiedzialności biznesu. Natomiast do kryteriów środowiskowych zalicza się m.in. sprawozdawczość ekologiczną oraz efektywność wykorzystania zasobów środowiskowych ${ }^{14}$. Warto także zaznaczyć, że oprócz wyżej wymienionych kryteriów pozytywnych w specjalistycznych indeksach ma zastosowanie także kryterium negatywne, którym jest wyłączenie spółek z takich branż, jak: hazardowa, alkoholowa, tytoniowa czy rozrywka dla dorosłych. Głównym indeksem z grupy Dow Jones Sustainability jest Dow Jones Sustainability World Index, który ma charakter globalny i obejmuje

${ }_{11}$ M. Marcinkowska, Odpowiedzialne przedsiębiorstwo na rynku kapitałowym - czyli o giełdowych indeksach zrównoważonego rozwoju, w: J. Duraj (red.), Przedsiębiorstwo na rynku kapitałowym, Wyd. UŁ, Łódź 2010, s. 128.

12 Ibidem, s. 130.

13 Ibidem.

14 J. Adamczyk, Indeksy zrównoważonego rozwoju w zarzadzaniu wartościa spółek giełdowych, „Finanse, Rynki Finansowe, Ubezpieczenia” 2013, nr 64, cz. 1, s. 10-11. 
cały świat. Oprócz niego klasyfikuje się spółki według podziału na Amerykę Północną i Stany Zjednoczone, Azję i Pacyfik, Europę oraz Koreę. Wśród spółek z największym udziałem w ogólnoświatowym Dow Jones Sustainability Worlds Index znajdują się między innymi Microsoft Corp, Nestle SA Reg, Bank of America Corp, Novartis AG Reg i Citigroup Inc. ${ }^{15}$

Tabela 2

Indeksy społecznej odpowiedzialności na świecie

\begin{tabular}{|l|l|c|}
\hline \multicolumn{1}{|c|}{ Dostawca indeksu } & \multicolumn{1}{c|}{ Indeks/ rodzina indeksów } & Data ustanowienia \\
\hline $\begin{array}{l}\text { Bayerische Hypo- } \\
\text { und Vereinsbank AG }\end{array}$ & HVB Nachhaltigkeitsindex & 2005 \\
\hline Calvert Group & Calvert Social Index & 2000 \\
\hline Corporate Monitor & Ethinvest Environmental Index & 1996 \\
\hline Deutsche Börse & $\begin{array}{l}\text { OkkoDax } \\
\text { DAXglobal Alternative Energy }\end{array}$ & 2007 \\
\hline Deutsche Börse i Sarasin & $\begin{array}{l}\text { DAXGlobal Sarasin Sustaiabi- } \\
\text { lity }\end{array}$ & 2006 \\
\hline $\begin{array}{l}\text { Dow Jones \& Company, STOXX } \\
\text { Ltd. i SAM Group }\end{array}$ & $\begin{array}{l}\text { DJSI STOXX } \\
\text { DJSI Euro STOXX }\end{array}$ \\
\hline E. Capital Partners & ECPI Index Family & 2007 \\
\hline FTSE Group & FTSE4GOOD & 2002 \\
\hline GreenTec Invest AG & GreenTec Climate 30 & 2001 \\
\hline $\begin{array}{l}\text { Hanover stock exchange i oekom } \\
\text { research AG }\end{array}$ & Global Challenges Index (GCX) & 2007 \\
\hline $\begin{array}{l}\text { KLD Research \& Analytics } \\
\text { i FTSE }\end{array}$ & $\begin{array}{l}\text { FTSE KLD 400 Social Index } \\
\text { FTSE KLD Global Sustainabil- } \\
\text { ity Index }\end{array}$ & 2007 \\
\hline MJRA & Jantzi Social Index & 1990 \\
\hline SAM Group i Dow Jones \& Co & DJSI World & 2000 \\
\hline SAM Group i Dow Jones \& Co & $\begin{array}{l}\text { Dow Jones Sustainability North } \\
\text { America Index }\end{array}$ & 1999 \\
\hline SECURVITA & Natur-Aktien-Index & 2005 \\
\hline UmweltBank AG & UmweltBank-AktienIndex & 2002 \\
\hline
\end{tabular}

Źródło: opracowanie własne na podstawie M. Marcinkowska, op. cit., s. 129.

Brytyjskim odpowiednikiem serii Dow Jones Sustainability Index jest opublikowana pierwszy raz w 2001 r. przez londyńska giełdę seria indeksów FTSE4GOOD Index. Jest to najbardziej znana w Europie grupa indeksów odnosząca się do kwestii społecznej odpowiedzialności i zrównoważonego

${ }^{15}$ Dow Jones SustainabilityTM World Index Fact Sheet, http://www.djindexes.com/mdsidx/ downloads/fact_info/Dow_Jones_Sustainability_World_Index_Fact_Sheet.pdf [dostęp: 10.03.2017]. 
rozwoju, opierająca się na ocenie czynników ESG (environmental, social and governance criteria), wskazujących, że oprócz troski o interes ekonomiczny przedsiębiorstwa powinny brać pod uwagę aspekty jak środowisko (environment), społeczna odpowiedzialność (social responsibility) oraz ład korporacyjny (corporate governance). Indeksy grupy FTSE4GOOD Index z założenia wykorzystywane mają być jako narzędzia do tworzenia portfeli inwestycyjnych ukierunkowanych na inwestycje społecznie odpowiedzialne. Ponadto indeks pomaga zidentyfikować firmy przestrzegające zasady zrównoważonego rozwoju i jednocześnie jest wyznacznikiem wysokich standardów, do których powinny dążyć firmy chcące rozwijać swoją działalność w sposób odpowiedzialny społecznie. Indeksy z grupy FTSE4GOOD Index wykorzystywane są także jako benchmark do śledzenia skuteczności zrównoważonych portfeli inwestycyjnych. Indeks klasyfikuje spółki wypełniające poszczególne kryteria pozytywne dotyczące takich grup czynników, jak: wpływ na środowisko, standardy pracy w łańcuchu dostaw, łagodzenie zmian klimatycznych, prawa człowieka oraz przeciwdziałanie korupcji; bierze pod uwagę także kryteria negatywne, wykluczające spółki, których profil działalności polega na m.in. na produkcji broni konwencjonalnej oraz jądrowej, wydobyciu i przekształcaniu uranu, wydobyciu węgla czy też produkcji tytoniu.

Ocena firm i branż pod względem wpływu na środowisko pozwala podzielić je na te o wysokim, średnim i niskim stopniu ingerencji w otoczenie naturalne. Ocena odbywa się na podstawie najróżniejszych dokumentów, pozwalajacych na pozyskanie najbardziej aktualnych i wiarygodnych danych. Analizuje się m.in. sprawozdania roczne spółek, bada dostępność informacji na ich stronach internetowych, a także inne ogólnodostępne materiały. Branże o największym wpływie na środowisko to m.in. przemysł chemiczny, budowlany, farmaceutyczny spożywczy, a także produkcja samochodów oraz rolnictwo. Do grupy o średnim wpływie zalicza się produkcję sprzętu elektronicznego, usługi hotelarskie i restauracyjne oraz transport publiczny. Natomiast wśród firm o najmniejszym wpływie na środowisko wymienia się telekomunikację, media technologie informacyjno-komunikacyjne oraz badania i rozwój. Klasyfikacja ta ma duże znaczenie, gdyż im spółka ma większy wpływ na środowisko, tym więcej rygorystycznych warunków musi spełnić, by móc być włączona do indeksu. Firmy „największego ryzyka i oddziaływania” muszą spełniać określone kryteria dodatkowe. Kryteria sa opracowywane z wykorzystaniem rozległych konsultacji rynkowych i są zatwierdzane przez niezależną komisję ekspertów. Kształtowanie kryteriów odbywa się przy wsparciu szerokiej grupy interesariuszy (m.in. organizacji pozarządowych, konsultantów, środowisk akademickich, społeczności inwestorskich oraz przedsiębiorców).

Seria indeksów FTSE4Good jest aktualizowana przez specjalnie powołany Komitet Polityki raz na pół roku (zazwyczaj w marcu i we wrześniu). Ponadto co kwartał publikowane są raporty prezentujące najróżniejsze statystyki indeksów, wyniki spółek, standardy społecznej odpowiedzialności, a także profil spółek wchodzących i opuszczających poszczególne indeksy ${ }^{16}$. Wśród spółek z największym udziałem w ogólnoświatowym FTSE4Good Glo-

16 J. Adamczyk, op. cit., s. 14-15. 
bal Index znajdują się m.in. Microsoft Corp, Apple Inc., Johnson \& Johnson, Wells Fargo \& Company, AT\&T. Natomiast jeśli chodzi o index europejski FTSE4Good Europe, grupa najwartościowszych walorów to Nestle, HSBC Hldgs, Royal Dutch Shell A oraz dwie szwajcarskie spółki farmaceutyczne Novartis (REGD) oraz Roche Hldgs (GENUS). Analiza FTSE4Good Global Index pozwala określić udział procentowy poszczególnych branż w jego strukturze. Największy udział w indeksie ma sektor finansowy $(24,46 \%)$, a za nim plasuja się sektor technologiczny $(15,9 \%)$, opieka zdrowotna $(13,86 \%)$, dobra konsumpcyjne $(12,24 \%)$ oraz usługi konsumpcyjne $(9,46 \%)$. Jeśli chodzi natomiast o podział ze względu na pochodzenie poszczególnych spółek, to kształtuje się on następująco: największy udział ma kapitał Stanów Zjednoczonych (48,68\%), następnie Wielkiej Brytanii (9,76\%), Japonii $(7,84 \%)$ oraz Francji $(5,28 \%)$ i Szwajcarii $(5,02 \%)^{17}$.

\section{INDEKS RESPECT}

Opublikowany po raz pierwszy 19 listopada 2009 r. przez Giełdę Papierów Wartościowych w Warszawie indeks giełdowy klasyfikujący spółki cechujące się najwyższym poziomem odpowiedzialności społecznej jest polską odpowiedzią na nieustanny wzrost zainteresowania inwestorów tematyką społecznej odpowiedzialności biznesu. Nazwa indeksu: RESPECT - w języku angielskim oznacza szacunek i jest także akronimem siedmiu angielskojęzycznych terminów ściśle powiązanych z tematyką społecznej odpowiedzialności przedsiębiorstw ${ }^{18}$ :

- responsibility - odpowiedzialność,

- ecology - ekologia,

- sustainability - zrównoważenie,

- participation - uczestnictwo,

- environment - środowisko,

- community - społeczeństwo,

- transparency - przejrzystość.

Indeks RESPECT jest pierwszym indeksem klasyfikujących spółki ze względu na ich zaangażowanie w obszar społecznej odpowiedzialności w Europie Środkowo-Wschodniej i obejmuje zarówno spółki krajowe, jak i zagraniczne spełniajace $\mathrm{w}$ najwyższym stopniu kryteria w zakresie płynności i wielkości. RESPECT to indeks dochodowy, co znaczy, że przy jego obliczaniu uwzględnia się zarówno ceny zawartych w nim akcji, jak i dochody z dywidend i praw poboru. Indeks powstaje w wyniku badania spółek notowanych na Giełdzie Papierów Wartościowych w Warszawie, a wejście w jego skład jest uzależnio-

${ }^{17}$ FTSE FACTSHEET 31.03.2017, http://www.ftse.com/Analytics/FactSheets/Home/Download SingleIssueByDate? IssueName=4GGL\%20\&IssueDate=20170331\&IsManual=\%20False [dostęp: 24.04.2017].

${ }_{18}$ Portal informacyjny projektu RESPECT, http://www.odpowiedzialni.gpw.pl [dostęp: 10.03.2017]. 
ne od stopnia spełnienia poszczególnych kryteriów odnoszących się do dobrych praktyk zarządzania w zakresie ładu korporacyjnego, ładu informacyjnego, relacji z inwestorami, a także kwestii pracowniczych, ekologicznych i społecznych. Aktualizacja składu indeksu dokonywana jest raz w roku. W szczególnie uzasadnionych przypadkach przewiduje się możliwość dokonywania zmian nadzwyczajnych na zasadzie ad hoc. Procedura oceny spółek składa się z trzech etapów ${ }^{19}$.

Pierwszy z nich polega na zidentyfikowaniu tych o największej płynności, które tworzą indeksy WIG20, mWIG40 oraz sWIG80. Aktualizacja tych indeksów odbywa się w ujęciu kwartalnym, na ogół w trzeci piątek marca, czerwca, września oraz grudnia, przy czym w marcu następuje rewizja roczna. Skład indeksu RESPECT jest natomiast aktualizowany raz do roku.

Drugi etap polega na przeprowadzeniu badania obszaru corporate governance spółek, czyli dobrych praktyk ładu korporacyjnego, a także relacji z inwestorami, które odbywa się we współpracy Giełdy Papierów Wartościowych w Warszawie i Stowarzyszenia Emitentów Giełdowych i oparte jest na ogólnodostępnych informacjach zawartych w raportach opublikowanych przez spółki, a także na stronach internetowych. W drugim etapie badania spółek stosuje się trzy kluczowe kryteria oceny. Pierwszym z nich jest obciążenie sankcjami Komisji Nadzoru Finansowego lub Giełdy Papierów Wartościowych w zakresie wypełniania obowiązków informacyjnych. W przypadku gdy na spółkę nałożone zostały wcześniej kary przez powyższe instytucje, zostaje ona wyłączona z możliwości sklasyfikowania w indeksie RESPECT. Drugim kryterium jest natomiast przykładne raportowanie w obszarze corporate governance oraz ładu informacyjnego. Badana jest jakość raportów bieżących, sytuacje korygowania wcześniej opublikowanych raportów, a także liczba korekt i ich waga. Trzecim kryterium oceny spółek aspirujących do indeksu RESPECT jest prowadzenie serwisu internetowego spółki według schematu wprowadzonego przez GPW, zakładającego analizę strony internetowej pod katem jakości komunikacji z inwestorami oraz jej skuteczności i szybkości, na które składają się ${ }^{20}$ :

a) sprawność w udzielaniu merytorycznych odpowiedzi na pomoca strony internetowej na pytania w zakresie relacji z inwestorami;

b) udostępnianie na stronie:

- podstawowych dokumentów korporacyjnych, takich jak np. statut spółki, czy regulaminy organów firmy,

- życiorysów zawodowych członków organów spółki,

- raportów bieżących i okresowych,

- sprawozdań z działalności rady nadzorczej

- komunikatów o strukturze akcjonariatu,

- kalendarium wydarzeń spółki,

- podstawowych wskaźników finansowych spółki,

19 J. Adamczyk. op. cit., 15-16.

${ }^{20}$ Portal informacyjny projektu RESPECT, http://www.odpowiedzialni.gpw.pl [dostęp: 10.03.2017]. 
c) zamieszczenie na stronie wyszukiwarki treści oraz jej właściwe funkcjonowanie;

d) umieszczenie w serwisie internetowym przekierowań do stron instytucji rynku kapitałowego, np. Komisji Nadzoru Finansowego, Giełdy Papierów Wartościowych czy też Stowarzyszenia Emitentów Giełdowych;

e) wykorzystywanie nowoczesnych sposobów komunikacji z inwestorami;

f) udostępnienie serwisu internetowego w języku angielskim.

Ocena serwisów internetowych dokonywana jest przez Stowarzyszenie Emitentów Giełdowych na moment badania, czyli w edycji wiosennej indeksu analizuje się kwiecień danego roku, natomiast w edycji jesiennej bada się stan strony na listopad danego roku.

Trzeci etap oceny spółek prowadzący do ustalenia składu indeksu RESPECT odbywa się przy wsparciu partnera projektu firmy Deloitte. Podmioty pozytywnie ocenione w drugim etapie proszone sa o wypełnienie ankiet, w których szczegółowo przedstawiają swoją działalność w odniesieniu do kwestii społecznej odpowiedzialności. Jest to ocena poziomu i stopnia kompleksowości działań podejmowanych przez spółki i adresowanych do grona ich interesariuszy, które stanowią wyraz ich szeroko rozumianej odpowiedzialności społecznej.

$\mathrm{Na}$ tym etapie dochodzi do bezpośredniej kontroli w badanej spółce mającej na celu potwierdzenie zgodności deklarowanych działań z zakresu CSR ze stanem faktycznym. Przeprowadzone przez firmę Deloitte rozpoznanie jest podstawą do podjęcia przez GPW decyzji o zakwalifikowaniu określonej spółki do składu indeksu RESPECT. W czasie przeprowadzanego badania pracownicy Deloitte dokonuja weryfikacji odpowiedzi zawartych w ankiecie - sprawdzają ich odzwierciedlenia w przekazanych przez spółkę dokumentach. Badana spółka otrzymuje gwarancję, że przekazane audytorom dokumenty i informacje sa traktowane jako poufne i wykorzystywane będą wyłącznie do zweryfikowania deklarowanej polityki społecznej odpowiedzialności. Odmowa poddania się kontroli stanowi podstawę do usunięcia spółki z badania i niezakwalifikowania jej do indeksu. W wyniku audytu przeprowadzonego przez Deloitte może dojść do obniżenia całościowej oceny spółki, ale także do jej podniesienia, gdy audytorzy uznaja, że zaimplementowane rozwiązania są wyższej jakości niż te zadeklarowane w ankiecie ${ }^{21}$.

Ocena spółek opiera się na analizie następujących czynników:

1. Czynniki środowiskowe (enivironmental):

- zarządzanie środowiskowe,

- ograniczanie oddziaływania środowiskowego,

- bioróżnorodność,

- aspekty środowiskowe produktów/usług;

2. Czynniki społeczne (social):

- bezpieczeństwo i higiena pracy,

- zarządzanie zasobami ludzkimi,

- relacje z dostawcami,

\footnotetext{
21 Ibidem.
} 
- dialog z interesariuszami,

- raportowanie społeczne;

3. Czynniki ekonomiczne (governance):

- zarządzanie strategiczne,

- kodeks postępowania,

- zarządzanie ryzykiem,

- zarządzanie ryzykiem nadużyć,

- audyt wewnętrzny i system kontroli,

- relacje z klientami.

Wymienione kryteria posłużyły także do oceny spółek w ramach ostatniej edycji indeksu.

W ankiecie X edycji indeksu RESPECT z 2016 r. zawarto w sumie 55 pytań, nie na każde pytanie jednak firma musiała odpowiadać. Odpowiedzi udziela się tylko na te pytania, które są wymagane dla danego działu przypisanego firmie. Spółki notowane na GPW podzielone są na 25 sektorów gospodarki narodowej, zgrupowanych w trzech głównych działach ${ }^{22}$ :

- przemysł, do którego zalicza się sektory: spożywczy, lekki, drzewny, chemiczny, farmaceutyczny, tworzyw sztucznych, paliwowy, materiałów budowlanych, budownictwo, elektromaszynowy, metalowy, motoryzacyjny, energetyka, deweloperzy;

- finanse, składający się z sektora bankowego, ubezpieczeniowego i rynku kapitałowego

- usługi, uwzględniający handel detaliczny, handel hurtowy, informatyka, telekomunikacja, media oraz hotele i restauracje.

Podział ten umożliwia obliczanie wskaźników sektorowych dla poszczególnych branż reprezentowanych na Giełdzie i łatwe śledzenie koniunktury panującej w różnych sektorach gospodarki. Ponadto najbardziej istotne sektory dla obrotu giełdowego te o największej liczbie spółek mają wyodrębnione własne indeksy, nazywane subindeksami sektorowymi. Kwestionariusz z 2016 r. dzielił pytania według schematu ESG. Znalazło się w nim 14 pytań z obszaru środowiska, 24 pytania odnoszące się do kwestii społecznych oraz 17 dotyczacych ładu korporacyjnego ${ }^{23}$. W wyniku przeprowadzonej analizy spółek ustalony został kształt X edycji indeksu RESPECT, który przedstawia tabela 3.

Przedstawione w tabeli dane obrazujące wartość indeksu RESPECT na przestrzeni kilku miesięcy potwierdzaja pozytywny trend wzrostowy całego indeksu. Nie można jednak traktować działalności z zakresu społecznej odpowiedzialności poszczególnych spółek jako głównej przyczyny wzrostu indeksu. Należy wziąć pod uwagę, że notowane w indeksie mogą być tylko spółki o największej płynności, a ich działalność w obszarze CSR jest tylko jednym z wielu czynników wpływających na ich wartość rynkowa.

\footnotetext{
${ }^{22}$ Ankieta RESPECT Index 2016 X edycja, http://www.odpowiedzialni.gpw.pl/pub/Respect_ Index_ankieta_edycja_X_pl.pdf [dostęp: 14.03.2017].

23 Ibidem.
} 
Tabela 3

Porównanie wartości spółek notowanych w indeksie RESPECT

\begin{tabular}{|c|c|c|c|}
\hline Spółka & Sektor & $\begin{array}{c}\text { Wartość rynkowa } \\
\text { na dzień } 13.02 .2017\end{array}$ & $\begin{array}{c}\text { Wartość rynkowa } \\
\text { na dzień } 24.08 .2017\end{array}$ \\
\hline KGHM & surowców & 13615064200 & 12845740600 \\
\hline PZU & ubezpieczeniowy & 11723113060 & 11577397000 \\
\hline PEKAO & bankowy & 11264576000 & 9954500000 \\
\hline BZWBK & bankowy & 10535526300 & 11411210350 \\
\hline PKNORLEN & paliwowy & 10480442500 & 11807710550 \\
\hline PGNIG & paliwowy & 9292757760 & 10884873600 \\
\hline PGE & energetyczny & 9186827280 & 11545284240 \\
\hline INGBSK & bankowy & 5734157500 & 6430192500 \\
\hline MILLENIUM & bankowy & 4261628800 & 4467446100 \\
\hline LOTOS & paliwowy & 3764620500 & 4977087930 \\
\hline ORANGEPL & telekomunikacja & 3528095650 & 3793512020 \\
\hline TAURONPE & energetyczny & 3068154600 & 4236975400 \\
\hline GRUPAAZOTY & chemiczny & 2957087040 & 2739946680 \\
\hline HANDLOWY & bankowy & 2691513600 & 2282233680 \\
\hline BUDIMEX & budownictwo & 2465913450 & 2690985000 \\
\hline ENERGA & energetyczny & 2063607200 & 2856530200 \\
\hline FORTE & $\begin{array}{l}\text { wyposażenie } \\
\text { domu }\end{array}$ & 1353894300 & 1184455800 \\
\hline GPW & rynek kapitałowy & 1299777600 & 1254910800 \\
\hline APATOR & elektromaszynowy & 863885850 & 785298950 \\
\hline BOGDANKA & surowców & 838390000 & 918759800 \\
\hline KOGENERA & energetyczny & 659981400 & 647988510 \\
\hline TRAKCJA & budownictwo & 599474160 & 475739280 \\
\hline ELBUDOWA & budownictwo & 562756850 & 525018200 \\
\hline PELION & ochrona zdrowia & 413066800 & wykreślona $\mathrm{z}$ indeksu \\
\hline PCCROKITA & chemiczny & 206435040 & 281482320 \\
\hline RAZEM & & 113430747440 & 120575279510 \\
\hline
\end{tabular}

Źródło: opracowanie własne na podstawie www.gpw.pl [dostęp: 25.08.2017].

Indeks RESPECT cieszy się sporym zainteresowaniem firm notowanych na GPW. Wdrożenie projektu RESPECT na warszawskim parkiecie z pewnościa przyczyniło się do promowania idei społecznej odpowiedzialności w polskim biznesie, a także wpłynęło na dostrzeganie przez inwestorów korelacji pomiędzy odpowiedzialnym, społecznym podejściem do prowadzenia działalności a wynikami finansowymi przedsiębiorstwa. Należy zauważyć bardzo dobre wyniki, którymi charakteryzuje się portfel indeksu. Od czasu jego pierwszej publika- 
cji do 22 lutego 2017 r. indeks uzyskał stopę zwrotu w wysokości $+79,67 \%^{24}$. Jednakże ocenę jego funkcjonowania i skutki wprowadzenia warto oprzeć na efektach realizacji założeń postawionych sobie przez GPW wraz z wprowadzaniem projektu RESPECT. Pierwszym z nich jest uruchomienie wskaźnika śledzącego koniunkturę wśród spółek odpowiedzialnych społecznie, będącego jednocześnie podstawą do tworzenia przez inwestorów własnych portfeli inwestycyjnych. Drugim założonym celem było zachęcenie spółek publicznych do większego zaangażowania w CSR i podwyższenia standardów w tym zakresie. Za trzecie założenie zaś przyjęto stworzenie jednej platformy informacyjnej dla spółek i inwestorów, którzy uznają za istotne takie czynniki, jak: etyczne prowadzenie biznesu, transparentność w kontaktach z interesariuszami czy dbanie o środowisko ${ }^{25}$. Dotychczasowe edycje indeksu RESPECT pokazują że założenia te zostały bez wątpienia osiagnięte.

GPW corocznie stara się pozyskiwać informacje na temat wpływu czynników związanych z ładem korporacyjnym, środowiskiem i społeczeństwem na decyzje inwestycyjne. Badanie to jest jednocześnie pewnym sposobem analizy, jak indeks RESPECT jest postrzegany przez interesariuszy giełdowych oraz w jakim stopniu biora go oni pod uwagę w podejmowanych decyzjach. Badanie ma formę ankiety online składającej się z 16 pytań, do której wypełnienia zaproszono grupę osób składająca się z ponad 300 profesjonalnych uczestników rynku kapitałowego (przedstawicieli domów maklerskich, funduszy inwestycyjnych i emerytalnych, firm doradczych, banków powierniczych i innych). Na podstawie ankiety ustalono, że większość ankietowanych (62\%) dostrzega korelację pomiędzy odpowiedzialnym podejściem do prowadzenia biznesu a wynikami finansowymi przedsiębiorstwa. Natomiast $27 \%$ respondentów nie wie, czy istnieje związek pomiędzy społeczną odpowiedzialnościa spółki a jej wynikami finansowymi. Jednakże w porównaniu z ubiegłorocznym badaniem odsetek respondentów dostrzegających pozytywne korelacje między odpowiedzialnym prowadzeniem biznesu a wynikami finansowymi wzrósł. Wyniki pokazuja, że każda z badanych osób zdaje sobie sprawę z istnienia indeksu RESPECT (ubiegłoroczne badanie wykazało znajomość na poziomie 94\% uczestników). Zupełnie odmiennie prezentują się jednak wyniki badania w kwestii odsetka osób analizujących indeks RESPECT. Tylko 23\% respondentów wskazało, że od czasu do czasu interesuje się notowaniami indeksu RESPECT (7\% wzrost $\mathrm{w}$ porównaniu z rokiem ubiegłym). Nikt z badanych nie wskazał, że robi to regularnie. Otrzymane wyniki powinny wpłynąć na podjęcie działań w zakresie informowania, jaki jest potencjalny, długofalowy wpływ poszczególnych kryteriów, które muszą spełniać spółki z indeksu RESPECT na wyniki finansowe podmiotów gospodarczych. W tym aspekcie niezbędne jest podjęcie działań przez GPW skutkujących zmiana postrzegania indeksu RESPECT oraz wzrostem zainteresowania nim wśród inwestorów. Innym dowodem na bardzo niskie zainteresowanie indeksem RESPECT jest

${ }^{24}$ GPW, https://www.gpw.pl/portfele_indeksow\#RESPECT [dostęp: 22.02.2017].

${ }^{25}$ T. K. Wiśniewski, RESPECT Index - spótki odpowiedzialne społecznie na gietdzie, w: L. Anam, E. Szul-Skjoeldkrona, E. Zamościńska (red.), Jak zyskać na odpowiedzialności?, CSRinfo, Warszawa 2012, s. 15-16. 
fakt, że tylko 31\% badanych jest w stanie wymienić co najmniej 5 jego spółek, co i tak jest wynikiem lepszym o $12 \%$ w porównaniu z ubiegłorocznym badaniem. Kolejne odpowiedzi na pytania zawarte w ankiecie dały także odzwierciedlenie, niestety małego, wpływu sklasyfikowania spółek w ramach inicjatywy RESPECT na decyzje inwestycyjne wśród uczestników rynku. Tylko 8\% respondentów uwzględnia fakt bycia danej spółki w indeksie, formułując rekomendacje czy też podejmując decyzje inwestycyjne. Martwić może stosunkowo niski procent (31\%) osób uważających, że funkcjonowanie RESPECT Index na GPW może wymiernie wpłynać na zwiększenie zainteresowania odpowiedzialnym inwestowaniem oraz wzrost rzeczywistego zaangażowania funduszy etycznych na polskim rynku. Tylko $31 \%$ badanych odpowiedziało twierdząco, $11 \%$ - negatywnie, a $58 \%$ - trudno powiedzieć. Fakt ten świadczy o potrzebie intensyfikacji działań komunikacyjnych i edukacyjnych podejmowanych w związku z funkcjonowaniem indeksu RESPECT. Respondenci badania, oceniajac go, wskazywali, jakie działania mogłyby być podjęte w celu zwiększenia atrakcyjności RESPECT Index i wzrostu zainteresowania tym instrumentem wśród profesjonalnych użytkowników rynku giełdowego. Badani wskazali bieżącą analizę pod kątem aspektów ESG dotyczącą spółek wchodzących w skład Indeksu (25\%) jako sposób wzmocnienia atrakcyjności indeksu RESPECT. Ponadto respondenci wskazywali m.in. opracowywanie raportów ESG dla pozostałych spółek notowanych na GPW (22\%), a także publikację raportów benchmarkingowych dotyczących rozwiązań ze sfery ESG wdrożonych w spółkach wchodzacych w skład Indeksu (14\% odpowiedzi). Mimo wzrastającego poziomu wiedzy dotyczacej indeksu RESPECT ciagle brakuje przełożenia na konkretne działania i chęci bieżącego wykorzystywania indeksu przez inwestorów. Świadomość funkcjonowania na rynku pierwszego w Europie Środkowo-Wschodniej indeksu spółek działających społecznie odpowiedzialnie nie wiąże się z rzeczywistym uwzględnianiem przy tworzeniu raportów analitycznych faktu notowania spółki w ramach inicjatywy RESPECT. Uzasadniona jest zatem aktywizacja GPW w kwestii dialogu z rynkiem inwestycyjnym, który z pewnością pozytywnie wpłynie na rozwój projektu RESPECT ${ }^{26}$.

\section{ZAKOŃCZENIE}

Rozwój koncepcji odpowiedzialnego inwestowania oraz indeksów społecznej odpowiedzialności biznesu na przestrzeni kilkudziesięciu lat jest bardzo pozytywnym zjawiskiem. Uwzględnianie czynników społecznych, ekologicznych oraz ładu korporacyjnego w działalności sprawia, iż przedsiębiorstwo staje się bardziej atrakcyjne inwestycyjnie. Wśród wielu funkcjonujących na świecie indeksów CSR szczególnie istotny z punktu widzenia polskich inwestorów jest indeks RESPECT publikowany przez GWP. Powołanie indeksu będącego pierwszą tego typu inicjatywą w Europie Środkowo-Wschodniej z pew-

${ }^{26}$ Raport z badania „Wpływ czynników ESG na decyzje inwestycyjne”, Deloitte, GPW, Warszawa 2016. 
nością pozytywnie wpłynęło na rozwój koncepcji społecznej odpowiedzialności biznesu wśród polskich przedsiębiorców i inwestorów. Jednakże zarówno postrzeganie indeksu, jak i samo wykorzystanie go przez inwestorów pozostawia wiele do życzenia i pokazuje, jak wiele wyzwań stoi przed zarządzajacymi projektem RESPECT. Przeprowadzone badanie potwierdza hipotezę autora o niskiej użyteczności indeksów społecznej odpowiedzialności przy podejmowaniu decyzji inwestycyjnych przez inwestorów. Mimo bardzo dużej świadomości istnienia indeksów CSR wciąż nie są one w praktyce regularnie wykorzystywane jako wskaźnik pozwalający na bezpieczne ulokowanie kapitału.

mgr Szymon Czopik

Uniwersytet Ekonomiczny w Poznaniu

szymonczopik@econsultingweb.pl

\author{
SOCIAL RESPONSIBILITY INDICES AS A METHOD \\ OF MEASURING CORPORATE CSR ACTIVITIES
}

\begin{abstract}
Summary
The recent years have seen a noticeable increase in the importance of corporate social responsibility (CSR) concepts in the business environment. As a result, the demand for tools measuring corporate social responsibility has been growing. Investors, too started to realise the particular importance of reporting which became apparent after the recent financial crisis that had significantly diminished the trust in the global market. In response to investors' expectations, financial institutions today publish indices of social responsibility. Currently, there are dozens of stock indexes based on CSR criteria, including the most popular Dow Jones Sustainability Index and the FTSE4GOOD Index, as well as RESPECT Index, the first CSR index in Central and Eastern Europe. Companies are increasingly frequently willing to implement CSR solutions and they also apply for inclusion in social responsibility indices. However, despite the high awareness of the existence of such indexes, they are not recognised by market participants as a key criterion to be used when making investment decisions.
\end{abstract}

